\title{
The Trusteeship Paradigm
}

\author{
The Formation and Reception of a Philosophy
}

\author{
Mohammed Hashas
}

\section{Introduction}

The trusteeship paradigm critiques both modernity and the tradition, and in doing so it navigates between what is commonly referred to as the "religious" and the "secular." As a critique, it proposes itself as an alternative to both. This chapter traces the development of the paradigm by outlining its major themes and intellectual stages as developed by Taha Abderrahmane since the 197os. First, it provides a biographical-intellectual sketch of Abderrahmane. Then it synthetically outlines the following five stages: 1) logic, 2) philosophy of language, 3) assessing the tradition, 4) spiritual modernity and moral philosophy, 5) political theology and political philosophy. Finally, it presents a review of the scholarly reception of this project. The chapter concludes with three reflective notes on language, Sufism, and ethics.

\section{$\mathbf{1}$ \\ Taha Abderrahmane: A Biographical-Intellectual Sketch}

Taha Abderrahmane was born in 1944, in the coastal city of El-Jadida, Morocco. His father was a " $f a q i \bar{h}$," or religious teacher, in the pre-schooling system called "masid" or "kuttāb," and he received his basic religious education through him. He obtained his Baccalaureate in Sciences in Casablanca after which he enrolled in the Philosophy Department at Mohammed v University in Rabat, where he received his BA Degree, before pursuing his first French doctoral title (troisième cycle) at the Sorbonne in 1972, and his $\mathrm{PhD}$ (Doctorat D'État) in 1985 on language, logic and philosophy (Abderrahmane 1979, 1985). He joined the university in Rabat as a lecturer in the early 1970 s and retired as a professor in 2005. He introduced the study of modern logic at the Mohammed v University, and other Moroccan universities soon followed suit. Besides Arabic he has an excellent command of French, and he has also learnt English, German, Latin and ancient Greek for direct access to philosophical works. He started publishing in Arabic in 1985 . 
Abderrahmane loved poetry in his youth. He was one of the youngest and earliest contributors to the Moroccan Writers Union founded in 196o. However, the ${ }_{1967}$ Six-Day War was a macabre shock to him, to the extent that it made him trade his youthful interest in poetry for philosophy. To describe this shift he composed a poetic verse, alluding to a classical line of Imru' al-Qays (d. c. 550): "today poety, and tomorrow thought" (al-yawma shir, wa-ghadan fikr) ('Abd al-Rahmmān 2014, 17). He joined the university when two formidable scholarphilosophers had just preceded him in publications and fame, i.e. Abdellah Laroui (b. 1933) and Mohammed Abed al-Jabri (1935-2010). He developed his philosophical project against the backdrop of the 1967 event and also partly to contest the scholarly contributions of these two scholars. As a young professor at the university with a religious tendency, his focus on the study of logic, language and philosophy methodologies proved not very appealing in a context dominated by Marxists and neo-Marxists, recounts Abbas Arhila, one of his close students, "followers" and a university professor of philosophy (Arhịla 2013, 11-40, 111-132). Ibrahim Machrouh, another student and professor of philosophy, narrates that the religious ethos underscored by two prominent Moroccan scholars influenced Abderrahmane, i.e. Allal al-Fassi (1910-1974), a renowned political and religious leader and scholar of al-Qarawiyyin University, and Mohammed Aziz Lahbabi (1922-1993), the first Moroccan professor of philosophy at the modern University of Mohammed $v$ in Rabat. Moreover, Ali Sami al-Nashar (1917-1980), the Egyptian philosopher who was influenced by Mustafa Abd al-Raziq (1885-1947) and his argument for an "Islamic philosophy" (see the introduction of this volume), was residing in Morocco and taught philosophy in Rabat, where he died in $1980 .^{1}$ Abderrahmane was his student, and it has been reported that the professor was impressed by Abderrahmane's work on language and philosophy before it was published, and predicted that it would have an impact on modern Arab thought (Mashrūh 20o9, 27-29).

The religious ethos in Abderrahmane's project stems from his personal experience. In the first edition of his book Religious Practice and the Renewal of Reason (1989), ${ }^{2}$ which drew the attention of more Arab intellectuals to

1 The fact that al-Nashar defended Islamic philosophical authenticity in ușūl al-figh, logic and theology might have influenced Abderrahmane who further digged into this strand of thought and later on rendered the science of $u s \underline{u} l$ al-figh part of the courses of modern logic that he introduced at the university.

2 All the works of Taha Abderrahmane are written in Arabic, except his two university dissertations referred to earlier. Here reference is to the English translation of the titles for ease of reference. 
him, he acknowledges the important role in his life of Sidi Hamza al-Qadiri al-Boutchichi (1922-2017), the spiritual guide of the Boutchichiyya order in Berkane, Morocco. He omitted this reference in later editions of the book, maybe for the critique he received for being an intellectual-philosopher and disciple in a Sufi order ('Abd al-Raḥmān [1989] 2006, 11). This acknowledgement would only find its way back to the public in a longer concluding chapter in the third volume of his trilogy Din al-Haya $\bar{a}^{\prime}$ (2017) — of which the literal rendering is The Religion of Humility or The Religion of Decency —, which can better be translated as The Religion of Testimony and Sight (2017), since testimony and sight impact one's worldview and ethos, which is the core idea of the trilogy.

Abderrahmane has lectured as a visiting Professor at the $\mathrm{Al}$ al-Bayt Univeristy in Jordan, in Sfax in Tunisia and Constantine in Algeria. He received membership of the Moroccan Royal Academy, besides other international bodies, like the Arab Philosophical Association in Amman, the Society for Intercultural Philosophy in Germany (Gesellschaft für Interkulturelle Philosophie), Bayt al-Hikma in Bagdad, the International Society for the Study of Argumentation in the Netherlands, and the International Union of Muslim Scholars. He was the editor of al-Munāzara philosophical magazine (1989-1993). He has presided over the Wisdom Forum for Thinkers and Researchers in Rabat since 2002. Abderrahmane received the Moroccan Writers Award in 1988 and 1995 for his two works, On the Foundations of Dialogue and Renovation of Islamic Theo$\operatorname{logy}$ (1987), and Renewing the Method of Assessing the Tradition (1994), respectively. He also received the Islamic Educational, Scientific and Cultural Organization (ISESCO) Award in 2006, for his book The Question of Ethics (2000), and the King Mohammed vi Award in Islamic Thought in 2014 for his overall contributions to Islamic scholarship (Mashrūh 20o9, 27-32).

Abderrahmane became known to the Arab public through Aljazeera Channel shows broadcast from Doha. His first appearance was on o3 May 2004, in al-Sharía wa-l-Hayāt (Sharia and Life) a famous TV show, at the time presented by Mahir Abdallah to speak about modernity and religion. Then on og March 2005 he figured in the TV programme al-Kitāb Khayr Jalīs (The Book as Best Company), presented by Khalid al-Harroub, to speak on the Arab right to philosophical difference. His most important appearance started on 19 May 2006 in the intellectual TV documentary Masārāt (Trajectories) consisting of six episodes, presented by Malik Triki, to speak on various aspects of his project. These encounters are chronicled and published in Dialogue as a Horizon for Thought (2013). Al-Jazeera Documentary channel also broadacast a documentary on him on 15 July 2017, in which he appears speaking and during which he visits the spiritual leader Sidi Hamza al-Qadiri al-Boutchichi in the city of 
Berkane (Morocco), where the headquarters of the sufi brotherhood are located (Aljazeera Documentary 2017).

During the month of Ramadan in 2006 Abderrahmane lectured as part of the International Lecture Series, known as al-Durūs al-Hasaniyya, in front of king Mohammed VI who is the patron of these lectures in his capacity of "spiritual leader," and "commander of the faithful" (amir al-mu'minin). He also lectured in the Carthage Palace in post-Arab Spring Tunisia in 2013, in front of Mouncef Marzouki who was the president of Tunisia at the time, and various Arab politicians and intellectuals. During the last few years, three annual conferences have been organized successively in his honour at the universities in Agadir, Marrakesh and El-Jadida in 2014, 2015 and 2016, respectively. Students and young scholars interested in his work have established various media outlets and websites to discuss and disseminate his ideas. Despite his health problems, and preference for writing over public visibility, he appears annually to give a public lecture in the national library in Rabat organized by the Maghareb Center for Civilizational Studies, a center consisting of senior and junior scholars and researchers influenced by his ideas (Hashas 2014, 2019b). On 21 October 2017, he gave a lecture at the Ibn Khaldun University in Istanbul. On 19 April 2017 a conference on "Taha Abderrahmane: Views and Horizons," was organized by reseachers at the International Institute for Muslim Unity at the International Islamic University Malaysia (IIUM) in Malaysia. In January 2019, he appeared in the French Le Nouveau Magazine Littéraire among the most influential thirty-five thinkers in the world. He appeared along with Azmi Bishara, based in Doha, from the Arab world, besides figures like Amartya Sen, Bruno Latour, Gayatri Spivak, Axel Hanneth, Judith Butler, Richard Dawkins, Chantal Mouffe, Alain Badiou, and others (Le Nouveau Magazine Littéraire, 2019).

This being said, what is it that makes of Taha Abderrahmane a remarkable philosopher? Abderrahmane aims not only to be a reformer but also an innovator in the Arab-Islamic philosophical tradition. He is critical of most major classical Muslim philosophers for one major reason: they mostly stopped at the achievements of Greek philosophy, and their reading of it was not innovative enough. He considers Ibn Rushd (Averroes, d. 595/1198) to be a mere "imitator" of Aristotle, and therefore the future of Arab thought should not be Averroest, as al-Jabri and many other modern Arab scholars call for ('Abd al-Rahmmān 2003, 119). The philosopher-theologians that tried to break away from the the dominance of Greek Aristotelian logic and that have earned his respect are alGhazāī (d. 505/1111), Ibn Ḥazm (d. 456/1064) and Ibn Taymiyya (d. 728/1328), not because they were anti-philosophy, but because they mastered it and tried to propose other pathways based on Arab-Islamic scholarship, particularly 
based on their readings of ușül al-figh as an authentic intellectual discipline in the tradition. He is also critical of the fuqah $\vec{a}$, the jurists, both in the past and present. He argues that they have focalized legal prescriptions of the Sharia at the expense of the moral and spiritual ethos behind them. Abderrahmane speaks of the "Rabat School" of philosophy, which aims at developing a philosophy that is productive, engaging, critical, innovative and ethicist in perspective (Hashas 2015, 71-74).

At the heart of his philosophical project lies the question of ethics. For him, the core of the Islamic message is ethical and reason is not a means to achieve and realize this élan. That is why philosophical and religious reasoning should make ethics their axis of thought. Human beings are first and foremost ethical beings, unlike the common Greek view that they are rational or political beings. He sees religion as the source of ethics. Revealed religion — and not human reason or man-made religions - are the ultimate source of human ethics, and he views Islam as the religion par excellence that champions this core value for human well-being. Human beings are either ethical or not. He puts it as follows in The Question of Ethics: "there is no man [i.e. humanity] without ethics", "there is no ethics without religion", "there is no man [i.e. humanity] without religion" ('Abd al-Rahmān 200o, 147-149). For him, and this summarizes his ethical theory as well as his philosophy of religion, "religion and ethics are one; there is no religion without ethics, and no ethics without religion" ('Abd al-Rahmān 2000, 52). "Ethicality" (al-akhläqiyya) is the essence of man, without which he is not human. Ethicality is simply the search for the good per se ('Abd al-Rahmān 2000, 14).

\section{The Formation of the Trusteeship Paradigm}

Abderrahmane's project of the trusteeship paradigm can be introduced by discussing five major intellectual interests and themes, which I list in chronological order, though at times they intertwine, from the 1970 on until present (mid-2019): (1) logic, (2) philosophy of language, (3) assessing the tradition, (4) spiritual modernity and moral philosophy, (5) political theology and political philosophy.

First: logic. Abderrahmane immersed himself into the study and teaching of modern logic, for which he became known at first. Besides his university dissertations published in French in 1979 and 1985, he published Formal Logic and Grammar (1983), On the Fundamentals of Dialogue and Renovation of Islamic Theology (1987) and Language and Balance, or the Multiplication of Reason (1998). In these works, he calls for introducing modern logic and mathemat- 
ics in the study of rhetoric, linguistics, and particularly in Islamic studies, in the study of usūl al-figh and the interpretation of the sacred text. His major critique of Islamic political movements as well as traditional Islamic universities and seminaries is that they have neglected the study of logic, especially modern logic; they kept teaching Aristotelian logic at best, and the dialogical logic of Marxist leanings for socio-political reasons during the heydays of Marxism in the Arab world. He praises the use of logic by classical Muslim theologians in their munāzarāt tradition and reclaims it for a modern ethical communication theory he calls "hiwāriyya," which can be translated as "entangled or deliberative dialogue," in On the Fundamentals of Dialogue.

Most importantly, it is the study of logic that enabled Abderrahmane to realize the limitations of human reason, and to consider it as an act among acts, and not as an independent entity or essence, which led him subsequently to develop his three-level categorization of reason: "abstract reason" (al-aql al-mujarrad), "guided reason" (al-aql al-musaddad), and "supported reason" (al-aql al-mu'ayyad). Reason is an act like any other act, like the seeing that the eye exerts, or the hearing that the ear enables. Briefly, abstract reason is an act that one exercises to explain and justify the act, based on particular proof, often concrete. ${ }^{3}$ As to guided reason, it is the rational capacity that takes into account three conditions in the process of activation: it should abide by Sharia law, bring benefit and prevent harm, be practical and practiced and not remain a mere thought or call for action. As for supported reason, it explores the capacity of knowing the internal identity and meaning of things, acts, or forms. It explores the objectives of revealed law and intentions beyond abstract rational and legal or functional explanations. It fuses the other two levels of reasoning to form a comprehensive understanding of being and existence. This level of rational practice that is open to the infinite inspiration from the unknown world(s) is akin to the world of scholarly-i.e. rational—practice of Sufism. The Sufis do not only know, and constantly strive to know, but also do practice what they know, with abundance, excellence, and humility ('Abd al-Rahmān $1989,17-18,58-66,121-156)$.

In The Question of Practice (2012) Abderrahmane revisits the issue of reason and its relation to revelation and practice, and distinguishes eight relations that have contributed to the modern emphasis on "abstract reason." Briefly, these relations exist in the form of dichotomies: reason and (1) speech, (2) essence, (3)

3 In an inaugural address entitled "The Pluralism of Values" for the new academic year at the university in Marrakech, Abderrahmane explains what he means by abstract reason by saying that it disregards revelation and the transcendetal in the study of "things" of the concrete world; it is descriptive reason ('Abd al-Raḥmān 20o1, 37, n. 30). 
sense, (4) heart, (5) ethics, (6) shar', (7) revelation, and (8) faith. Abderrahmane thinks that human reason is not confined to these eight limitations or opposing definitions. Human reason does not limit itself to language, though it is its most expressive form. It is also not the essence of human beings, nor can the senses alone capture its vast horizon that can be as inspiring as the senses themselves, which do not work within a limited space or time or in one direction. Opposing the work of the heart to that of reason, or the brain, is the dichotomy most critiqued by Abderrahmane, and is also the most important critique in his overall project. He takes the heart as the center of human rational practice. Rational expansion happens when the heart is able to embrace a horizon that is infinite and open to non-concrete inspiration. The heart harbors guidance to ethical practice. As to ethics, Sharia laws, revelation, and faith, these do not oppose nor antagonize rational choices if they are guided by the heart, by its indepth, natural, i.e. fitrī, inclinations ('Abd al-Rahmmān 2012, 55-110).

Second: philosophy of language. Abderrahmane worked on the philosophy of language, first of all for his Master's thesis, published as Language and Philosophy: An Essay on the Linguistic Structures of Ontology (1979), but most importantly in the following two volumes: The Essence of Philosophy, Vol. 1: Philosophy and Translation (1996), and The Essence of Philosophy, Vol. 2: On Philosophical Discourse (1999). In the latter work he coins the term of "figh al-falsafa," calls for the study of ușul al-figh and the sciences it requires, to comprehend (faqaha) the philosophical genius in the Arab-Islamic tradition. If the Greek tradition is kept as a model, no originality would be found in the Arab one. It is also in these works that he makes a case for creativity in the practice of philosophical translations, otherwise mimicry and "tasteless" translations result in sterile and meaningless concepts in Arabic. To illustrate this, he gives examples from erroneous translations in classical as well as modern Arabic translations of Greek or European concepts. It is at this stage that he emphasizes the vital role of the native language for any philosophical, and consequently cultural, renewal ('Abd al-Raḥmān 1996; 1999). For example, in a lengthy section he argues that each language structure and logic expresses its rationality differently. He proposes the Arabic "unzur tajid" (literally, "See(k), you find") as the equivalent of the Cartesian "I think, therefore I am." This Arabic rendition of modern Cartesian philosophy of the assertion of the Self (Subject) as a capable existential entity received harsh critique from the Lebanese thinker Ali Harb. The latter states that Abderrahmane with this cultural translation "decapitated" the subjective assertion of the modern Cartesian Self, and replaced it with an obedient Self that "finds" what has already been destined to it, or revealed to it through orders "See(k)!" (Ḥarb 1996, in Bin 'Addī 2012, 180-184; I will return to this point below). 
Third: assessing the tradition. When al-Jabri appeared on the Arab intellectual scene with his project of the "critique of Arab reason" and distinguished between the rational Maghreb and the mystical Mashreq (Eyadat, Corrao and Hashas 2018), Abderrahmane responded with a heavy critique of this "reductionist" and "divisionist" approach of reading the tradition. As a first reply, he published Renewing the Method of Assessing the Tradition (1994), to be followed afterwards by texts that belong to this stage-i.e. assessing the tradition and critiquing contemporary Arab philosophical projects-The Arab Right to Philosophical Difference (2002), and The Islamic Right to Intellectual Difference (2005). It is in these texts already that the contours of his trusteeship critique begin to show. Major Arab-Muslim theologians-philosophers are critiqued for being imitative, uncreative, and uncritical of modernity. In The Arab Right to Philosophical Difference, for instance, he problematizes the modern role of philosophy and the philosopher. He says that philosophical questioning no longer needs to seek the "truth", or to nurture "critique" only, but it has to raise the "responsible question", which can certainly be put in plural too. What is required of the modern philosopher is to remain responsible with his abstract theoretical questions and productions. That is, $\mathrm{s} / \mathrm{he}$ has to be accountable for what he says and theorizes. Here, he underscores the ethical and practical role of the philosopher. He states that practice is fundamental to the process of philosophizing, a point with which he challenges the ethical agency and engagement of the philosopher. Moreover, in the same work he also reverses the question of universality of reason and philosophy at large and argues that in modern globalized times, in which one form of philosophy dominates, universality has to pass through local (i.e. geographical) and cultural questions. Philosophy has to be local first, and with its local needs and questions the universal becomes apparent, while starting by claiming universality may be a form of disregarding local traditions and championing hegemonic ones that are supported by economic and military means. In the Arab context he says, "we, the Arabs, want to be free in our philosophy" ('Abd al-Rahmān 2002, 22).

In The Islamic Right to Difference (2005) Abderrahmane critiques hegemonic thought, with major reference to the American cultural and political dominion. He presents an Islamic ethical critique of consumerism and the alternative principles of plural co-existence. In his common way of detailed argumentation and counter-argumentation, he presents three major principles that celebrate diversity of thought: the principle of tolerance, the principle of recognition, and the principle of rectification (mabda' al-tașwib). He supports these principles with an argumentative form of the meaning of ethical jihad and the path to spiritual and ethical excellence ('Abd al-Raḥmān 2005). 
Fourth: spiritual modernity and moral philosophy. It is already with Religious Practice and the Renewal of Reason (1989) that Abderrahmane's emphasis on ethics, and not reason, as the core of his project starts to take shape in his philosophy. After having produced theoretical texts on the role and tasks of philosophy and translation and after having seen the development of various theoretical reformist projects in the Arab-Islamic contexts, he appeared not to be satisfied. He would synthesize this and launch it in a new line of thought: ethics. He does this in a twofold manner: first, he deepens his critique of Western modernity and he builds his trusteeship paradigm, or trusteeship critique as he also calls it, in its aftermath as its replacement or correction.

I present a few notes for each stage of this work on ethics. It is in The Question of Ethics (2000) at first that ethics become not only the essence of man, and of Islam, but also the essence of any human change to a better future, or what he calls a "civilization of ethos" ('Abd al-Raḥmān 2000, 146).

Abderrahmane's core philosophy is that man is first and foremost an ethical being, and the more he develops his "ethicity" or "ethicality" (akhläqiyya), the closer he gets to the level of humanity. Rationality is only a means to this end. As noted earlier, for him religion is the source of ethics, there is no man (i.e. humanity) without ethics, i.e. man without ethics is not man, though he can still be considered to be man if his rationality ('aqläniyya) alone is measured. The existence of man parallels the existence of ethics, and vice verse. They are not chronologically distinct. Ethics is what renders human beings human. It is their identity and essence. He differentiates between three levels of ethics, like the categorization of reason above: abstract ethics, guided ethics, and supported ethics. The first remain functional and utilitarian, at the surface of what they render human beings. Guided ethics cling to (religious) laws, without reaching their spirit, which supported ethics teach and aim at. The latter beget benefit not only to the self but especially to the other, and to the inanimate world as well. Supported ethics fuses spiritual teachings with practice, and expand their benefit to the rest of the world, and this is the message of Islam. This is what makes Islamic ethics universal ethics, according to Abderrahmane.

Among his various concepts, sub-concepts, principles, and pillars, four principles of "supported ethics" - the third and highest stage in Abderrahmane's categorization - can be briefly mentioned here. The first is the principle of obligation (mabda al-ijā $b)$ : this means that ethics in this stage are not optional. They are the core of human identity, without them evil or wrong occurs. The second is the principle of reproduction (mabda' al-takthir): that is, ethics do not have one shape, or one form, or one place. They change according to time, space, and the consequences they engender. The third is the principle of organization (mabda' al-tartïb): that is, ethics are infinite in their scope. The more the 
individual is committed to them, the more ethical attitudes and satisfaction they engender. This means that ethics do not all have the same value and can be classified. The fourth is the principle of expansion (mabda' al-ittis $\left.\bar{a}^{c}\right)$ : that is, the ethicist feels overwhelmed and completely encompassed by the ethical message he carries. No space of thought or behavior is left uncovered. Ethics are expansive, comprehensive. Without ethics the individual feels life is meaningless ('Abd al-Raḥmān 2000, 81-84).

In the same vein, Abderrahmane develops his modern ethical theory further in The Spirit of Modernity (2006), where he presents his possible "Islamic" modernity, which he also calls "spiritual modernity" ('Abd al-Rahmān 20o6, $5^{6-59}, 67$ ). Abderrahmane distinguishes between the spirit or essence of modernity, which in his view can be multiple in accordance with the diversity of world traditions and how they approach it, and the fact of modernity, or le fait accomplit of modernity, as it manifests itself in the Euro-American version. The vertical man - in contrast with the modern secular-atheist horizontal maninvokes his creative efforts for a modern modernity from his fields of energy that are spiritual in the first place. It is also in the same work that he proposes a modernist and creative reading of the Qur'an, one that is innovatively (1) "historicist," (2) "rationalist," and ethically (3) "individualist" ('Abd al-Raḥmān 2oo6, 175-206). In this three-level interpretation of the Qur'anic ethical cosmology, Abderrahmane presents a detailed critique of Western modernity, how it desacralizes the sacred and how modern Muslim philosophers and intellectuals have followed such desacralizing paradigm of differentiating, which brought them the opposition of reason and revelation, religion and politics, the individual and society (Hashas 2013, 2015, 2019a, 2019b).

Second, Abderrahmane charts a new territory for Western modern scholarship with critique, as a way of solidifying his proposal of a new paradigm of thought. He engages with some prominent European philosophers in The Misery of Secularism (2014) where he especially discusses four approaches of modern separation of ethics from religion: the naturalist, the critical, the social, and the humanist, with major reference to Jean-Jacques Rousseau (1712-1778), Immanuel Kant (1724-1804), Émile Durkheim (1858-1917), and Luc Ferry (b. 1951), respectively. Abderrahmane suspects that secularism - which he translates in Arabic as dahrāniyya, and which can also be translated back to English as materialism - is about the separation of religion and politics, or vice versa, which in his view is/was a European historical problem. He rather considers secularism to be a philosophical project that separates ethics from religion, knowing that he sees the latter as the source of ethics. He furthers his critique in Post-Secular Loss (2016) in which he argues that deserting religion is the result of the secularism he critiqued earlier. In this book he presents and 
afterwards debunks some five major approaches of man and humanity in modernity: the sadist man, the superman, the sovereign man, the Oedipus man, and the neurotic-obsessionist man, with major reference to Marquis de Sade (1740-1814), Friedrich Nietzsche (1840-1900), Georges Bataille (1897-1962), Sigmund Freud (1856-1939), and Jacques Lacan (1901-1981), respectively. Overall, Abderrahmane argues in detail that the ethics these philosophies defend are driven by human whims, relativism, and have no central source or authority for (ethical) guidance, which is why, again, he finds in revealed religion(s) the answer and the source of his ethical theory and paradigm he calls the "trusteeship paradigm," and the "trusteeship critique." In these books, and others, Abderrahmane also engages with other contemporary moral philosophers of international acclaim, who may appear close to his views on the importance of ethics, like Hans Jonas (1903-1993), Emmanuel Levinas (1906-1995), and Hans Küng (b. 1928), but he critiques their approaches since he considers them "too secular," thus unable to truly transform human beings from within.

As noted earlier, the seeds of such a paradigm can already be found in different chapters in The Question of Ethics, and The Spririt of Modernity. Two other major books have bolstered his critical project: The Islamic Right to Intellectual Difference (2005) referred to above, and The Spirit of Praxis (2012). In the first, he underlines the fact that ethics equals (good) acts or practice, and that theoretical ethics that remain in the abstract are useless. Ethics are intended for this world, to be lived and practiced, and not only preached or theorized. In the second, he defends the "Islamic culture(s)" in general against the hegemony of modern consumerism and self-gratification.

In 2017, Abderrahmane published the trilogy of The Religion of Testimony and Sight (2017), or literally The Religion of Decency. Here he wraps up his ethical theory in new concepts and foundations, which have appeared earlier in various texts. He devotes the first volume to the sources of this paradigm of trusteeship, the second to studying the case of the new media and technology in the light of this critical paradigm, and the third to the case of what the veil (hija $\bar{b})$ connotes and denotes in modern Western philosophies and what it connotes and denotes in this Islamic ethical paradigm. Apart for some minor digressions, only some relevant notes on the first volume will be made here. Abderrahmane restates the Qur'anic cosmology that is behind his project. He refers to two worlds: 'älam al-malaküt, and 'älam al-mulk, or simply put, the metaphysical world and the physical world. The second is the space where humans are responsible vicegerants, and the first is the original world from which humans obtain their values, and after which they quest. Three sources or concepts bind human beings to this metaphysical world: shahāda (testimony), amāna (trust), and tazkiya (self-critique, or, more literally, self-purification). 
Testimony is the first pact humans have had with the divine, and it is based on the Qur'anic story (al-A'rāf, Q 7:172-174) wherein the human being (insān) not only testified (shahida) but also saw (shāhada) the moment in which they pledge allegiance to God that He is the Lord of all worlds. This act of visualized testimony makes humans responsible on this physical world to this ancient pact made in the metaphysical world, and preserved in human memory, thus human's constant search for the divine and connection with the transcendent.

Trust, as a second principle in this paradigm, is essential too for the maintenance of human contact with a higher source of values and ethics. It is based on a Quranic verse (al-Aḥzāb, Q 33:72-73) wherein man willingly accepted the divine message of belief and being a vicegerent on earth. For Abderrahmane, this makes human beings free to believe or not, and also free to maintain the responsibility over the cosmos, and earth in particular. In all cases, they have to be accountable for their choices, since they are originally free, and they have the capacity of reason to judge. Failing to be responsible means that man either falls in treason (khiyāna) or possession (hiy äza) of that which is not his/hers. For Abderrahmane, modern man has betrayed the original pact, the "pact of trust", and has thus fallen prey to the curse of excessive possessions, i.e. excessive consumerism without ethics, at the expense of sharing with "others" - sharing, a great value of "excellence", or ihsān, and belief. The "pact of trust" has a positive impact on the individual, society, and the world at large. It seeks goodness per se, hence the earlier equasion of belief = ethics = practice.

As to self-critique, or self-purification, the third principle of this ethical paradigm, it is a means either to boost the benefits of doing good, and being good, or a means to correct wrongs. It is a principle that emanates from a Qur'anic verse (al-Baqara, Q 2:151-152). It stands between the world of "witnessing" or "testimony," and the world of "seeing," i.e. between the metaphysical and the physical. Self-purification is a discipline that incites humans to restrain their desires, wishes, and appetites. It is a mode of self-critique, selfelevation, and self-realization. This discipline cannot be ethical if it does not take a higher example for good behavior. The divine names (al-asmäa al-husnā are the major source of such a discipline for Abderrahmane. It is through them that human beings can be creative, innovative, and open to newness. Their teachings are infinite. They liberate human beings from themselves and from their peers.

Fifth: political theology and philosophy. Abderrahmane has also written on politics, political theology and political philosophy. The first work that traces this strand of writing in his overall project goes back to The Arab Right to Philosophical Difference (2002). The book was published after the second Palestinian Intifada of 2000 and used this political event to speak of the dire need for an 
"Arab philosophy," based on its socio-political status quo, needs, and aspirations - as referred to above in "assessing the tradition" section. It was already noted that to defend the plurality of philosophical practice and worldviews, Abderrahmane argues that it has to start locally, however cosmopolitan or universal it becomes. It is here that he speaks of the Greekization, Europeanization, Judaization, and Germanification of philosophy, and calls for Arab philosophers to build their freedom based on their own domain, language, and tradition. He speaks of a "philosophical awakening" (qawma falsafiyya). Next, Abderrahmane speaks of a "political awakening" (qawma siyāsiyya) and he introduces different levels of this awakening, based on ethical empowerment. He also introduces the concept of "awakend youth" to speak of different humanity levels-i.e. insāniyya (humanity), rujūla (wo-manhood), and murüa (magnanimity) — based on ethical enrichment and the ability to give to the other. It is this ethical element that can impart Arab philosophy a universalist perspective again (Hashas 2019b). In the same book, he pays special attention to the Palestinian cause and argues for resitance at all levels, philosophic and political, including physical resistance against Israeli dehumanization of the Palestinians and their rights to freedom and liberation. He speaks of different levels of the "awakening" and the different reactions of Arab political regimes to the Palestinian Intifada and its youth awakening. He does also engage with these concepts and the Palestinian cause in another shorter book, entitled Modernity and Resistance (2007).

In The Spirit of Religion (2012), a voluminous work, the political theology and philosophy of Abderrahmane starts to take clearer theoretical grounds, based on a critique of both modern secularism that takes the place of religion, according to him, and the Islamic use of religion in politics exemplified by the theorists of Sunni and Shia political Islams. He launches his critique of political Islamic Salafists and their superficial understanding of Sharia law, their inability to pay attention to the overall ethical message of Islam, and their inability to fathom what secularism means, i.e. submission of the religious ethos to utilitarian ethics that can endanger human collective flourishing. He argues that the religionists (i.e. practitioners of political Islam) and the secularists do in the end use the same means of reaching power, clinging to it, and subduing to it, one through figh law and the other through democratic means that does not take the spiritual dimensions of human beings into account. Both versions of practicing politics seek power (tasayyud). It is in this work that he introduces the two dimensions of figh: one purely legal, thus rigid, ( figh i'timār $\bar{\imath}$ ), based on rituals and obligations, and the other ethicist ( figh ittim$\bar{a} n \bar{\imath})$, based on the general ethics of Islam, thus changeable according to human needs, but in the end still within Sharia limits. These differences he develops 
especially in the first volume of his trilogy referred to earlier, The Religion of Testimony and Sight (2017).

His most recent Posts of Resistance (2018) is an engaged critique of especially Saudi Wahhabism and Shi'i Khumeinism, this time not only because they have usurped what figh means in politics, but also because with their failures they have given space to Western hegemony in the region, especially to the us and Israel, have manipulated their defense of the Palestinian cause, and have, consequently, weakend national Arab and Islamic societies at large. This work can be considered to be the most direct and critical of state regimes among his overall writings. With this work he challenges the stereotype that Sufis or Sufi scholars are "silent" in the face of state institutions and regimes. Even though he was criticized for "Salafising philosophy" [from Salafism], for the remarkable emphasis on religion in his project, he published two works in defence of dialogue, and in refutation of violence: Dialogue as a Horizon for Thought (2013), and The Question of Violence (2017). Some of his ideas, originally short lectures on education, youth, and renewal, are published in a booklet in simple language for the wider public: From Sterile to Generous Humanity (2017). At the heart of these texts, internal ethical jihad is given the credit for any desire for change, be it socio-political or intellectual.

\section{The Reception of Trusteeship Paradigm}

Despite his many publications (25 books so far, in the beginning of 2019), Abderrahmane is hardly known in the international scholarly community in the field of Arab-Islamic studies. Notable edited volumes and anthologies dedicated to contemporary Arab and Islamic scholarship hardly refer to him and his project in European languages (English, French, German, and Italian, to name only these) (Hashas 2015). Reference to his project has emerged only since the 200os (Lahoud 2005; Hallaq 2013, 2019; Hashas 2013, 2014, 2015, 2019a, 2019b; Moosa 2014; Kigar 2015; Bevers 2016, 2018; Borik 2016; Mimouni 2016; Belhaj 2018; Tais 2018). As to the works that study his project in Arabic, they too are not many, and are mostly synthetical so far, written by his students or academics influenced by his ideas (Mashrūh 2009; Bū Zabra 2011; Bin 'Addī 2o11; Arhīla 2012; Humām 2013; Harī 2014; al-Naqqarī 2014; 'Abd al-Raḥmān and Marhụum (intr.) 2015; Maqūra 2015; al-Shabba 2016; Bal'aqrūz 2017; Amaqdūf 2018; Ḥabbāsh 2018).

Despite his wider readership in the Arab world, only a few well-known Arab philosophers and scholars have commented on his thought in some journal articles or newspaper articles, instead of fully engaging with him in a scholarly 
exchange. For instance, al-Jabri did not reply to the harsh critique levelled at him especially in Religious Practice and the Renewal of Reason (1989), and in Renewing the Method of Assessing the Tradition (1994). The two philosophers never participated in the same events or at the same table, with the exception of one conference that dates 21-23 April, 1978, in the Faculty of Letters at their university in Rabat. The conference was a celebration of the 8ooth anniversary of Ibn Rushd and his legacy. It is there that Abderrahmane started his critique of al-Jabri and his reading of Averroes and the tradition in general (Harī 2014, 7). Despite their intellectual disagreement, cooperation between the two philosophers is not non-existent. At least there is one trace that is found: al-Jabri contributed a chapter to al-Munāzara magazine that Abderrahmane edited between 1989 and 1993, precisely to issue n. 6, of 1 December 1993 (Al-Jābrī 1993, 9-24). Abdallah Laroui did not engage with him either, apart from his critical notes in some of his memoirs in which he accuses Abderrahmane of introversion, of refutation of any idea that is "Western" and "modern", and of being harsh in critiquing modern and classical Arab-Muslim philosophers. Laroui believes that using the tradition and its classical methods for modern renewal is not the path to follow. An epistemological break is needed, which, according to him, Abderrahmane does not seek (al-'Arwì 2005). Kamal Abdellatif, who generally pursues the line of thought of Laroui, joins the critique, and thinks that Abderrahmane's spiritual ethos does not serve historicist studies nor Arab changing societies ('Abd al-Lațif 2018). As to Abdelilah Belkeziz, a political theorist and Arabist à la al-Jabri, his disapproval of the project of Abderrahmane made him not mention him at all in his thick volume on critical Arab thought (Balqazīz 2014).

In the Mashreq (Levant), some renowned contemporary Arab scholars have engaged with Abderrahmane in various journal and newspaper articles. For example, in reaction to Abderrahmane's two volumes on philosophy, in which he tries to theorize the practice of both philosophy and translation, the Lebanese Ali Harb accuses him of misusing philosophy and logic to simply refute whatever is not "originally" Arabo-Islamic. He also refuses the way Abderrahmane translates the Cartesian cogito into Arabic, as seen ealier (Harb 1996; 1999). His compatriot Ridwan al-Sayyid, too, shows great respect for the scholarship of the philosopher, and the profound ethical weight he has put in his project. However, commenting on Abderrahmane's The Spirit of Religion, published in 2012, a delicate moment in the Arab Spring revolts, al-Sayyid expressed his fear in a newspaper article against the staunch critique the author levelled especially against the notion of the modern state, be it secular or religious. In the article, al-Sayyid warned that focalizing individual ethics, and refuting the notion of the state that Arab societies need for change can 
pave the way for violent extremists to emerge as an alternative for a sovereign authority (al-Sayyid 2012). Al-Sayyid continued his critique of the philosopher when he published Posts of Resistance (2018), since the book launches another strong refutation of alliance with hegemonic powers (American and Israeli) in the region, using religion in politics. Al-Sayyid took this as an introvert and isolationist attitude towards the world from an important Arab philosopher, an attitude the troubled Arab world does not need (al-Sayyid 2018). The Jordanian Fahmi Jadaan does not stand far from this critical reception of Abderrahmane. In an article on ethics and politics, he thinks that the religious ethics of the studied philosopher does not respond to the complexity of societies and their differing, or opposing, moral views (Jad'ān 2014, 13-23). The Mauritanian scholar Abdellah Seyyid Ould Bah, however, makes a different note in his scholastic book about influential Arab scholars of the second half of the 2oth century. Out of 33 figures, to whom he refers as "thinkers", it is only Taha Abderrahmane that he refers to as "philosopher" (Sayyid Wald Abāh 2010, 71$79)$.

\section{Reflective Closure}

This chapter has synthetically chronicled the development of Taha Abderrahmane's philosophical project of the trusteeship paradigm. Besides the intellectual stages synthetically outlined above, three further points will be made below as a form of closure: on language, "spiritual self-criticism," and ethics.

First, Taha Abderrahmane's philosophical language is unique. In every book, he develops various new concepts and sub-concepts that are originally Arabic or derive from an Arabic root, to the extent that a whole dictionary devoted to his philosophy could be collected. He argues for each concept in a logical manner. He often presents three arguments of a certain idea that he wishes to critique, then he presents his own replies to them. Often each of them consists of three other sub-arguments, and each sub-argument is often further subdivided. This makes his argumentation unprecedented among contemporary Arab philosophers and scholars. He states that he does not wish to be a historian of ideas as most contemporary scholars are. His background in the study as well as teaching of logic must have had this lasting influence on him. It is true that it is an excessive dictionary that he has accumulated over the years, that many of his concepts overlap and at times bear the same meaning put in different words, but this is justifiable if we bear in mind that one of his projects is not only to propose a new and argumentatively sophisticated ethical theory in Arab-Islamic philosophy but also to revive Arabic as a language of 
philosophy. For him, philosophizing and practicing philosophy freely, can only happen within a rich linguistic tradition. With his over-argumentation in his books he wishes to raise the level of philosophical practice in the Arab and Islamic world at large, and to coin terms that belong to this linguistic tradition and its worldview. With this feature of his work he stands as a genuine philosopher of his time.

Second, and this relates to the private sphere and to the meaning of spirituality in modern times, applied ethics in the trusteeship paradigm are rooted in the tradition, however rationally expounded. Ethics without consistent practice are null and void in Abderrahmane's project. Being a philosopher of logic and at the same time a devout man who belongs to the Boutchichiyya Sufi path has been received with critique from some Arab "secular" thinkers, as referred to above. The personal life of Abderrahmane may be a manifestation of his philosophy, but he also says this is his personal life and choice, and it does not bind his "readers" or "disciples." What could be deduced from this is that he rejects modern spirituality that is individualist, bound by no tradition or limits. For him, Sufism is a connexion to the ethical limits taught by the tradition. The future homo moralis knows the self and its powers and desires, and knows on what grounds it stands as well as its limits, before he can "save" the future. This is a form of liberation theology in the trusteeship paradigm, but the challenge facing it, especially in the Arab-Islamic context it focalizes, is that belonging to the tradition now has diverse manifestations. While it could remain a challenge at the abstract level, for the realization of the "perfect being" or "perfect modern wo/man," on the ground, with which the trusteeship project remains bound, it may be too challenging. Being Muslim and being Islamic has been disrupted by the Euro-modern secularist paradigm for over the last two centuries, and reclaiming it now with such a highly complicated Sufi philosophy may not be embraced by the Islamic worldviews whose belonging to the tradition takes different paths. Al-'amal al-tazkawū, or "spiritual self-criticism" as I translate it, is too demanding to be adopted by everyone in society for renewal for Muslims, and for reforming modernity in non-Islamic societies, for a shared better world. Spiritual paths have always been diverse in Islamic history. In modern times they have also taken different political and apolitical attidudes. However, it should be understood that Abderrahmane's Sufi dose for internal renewal, before any external change, challenges popular, and at times folkloric, Sufism, as well as modern individualist spirituality that is self-centered, and praxis-less. The trusteeship's use of "spiritual self-criticism" is learned, philosophic, as well as pietist. It navigates between the secular and religious, the public and the private, to create a third worldview that is neither secular nor religious as commonly understood. 
Third, the trusteeship paradigm seeks the formation of a modern Islamic theory of ethics that keeps the core of the tradition alive, i.e. practical faith, in the age of modernity in which faith and practice have generally been separated due to the secular versus religious dichotomous thought. Trusteeship seeks the restoration of faith to the modern issue of ethics and its varigated theories and tendencies, mostly the secular or atheist ones. Here, Abderrahmane moves the debate on ethics and religion in general to a new focus, which is already traditional but based on the modern context and needs, i.e. that Sharia's core message is ethics, and not law, without justifying the disregard of law (fiqh) because modern times requires it, as a number of other modern Islamic projects of reform aim at. Abderrahmane rather turns Islamic legal theories, and Sharia objectives in general, into fields of energy for genuine philosophical thought about modernity challenges and the future of humanity at large. He does this with confidence from an Islamic perspective, which critics of religion in the public sphere of the modern liberal-secular state may find traditional, archaic, and may then just ignore it without further ado. Spiritual modernity as presented in the trusteeship paradigm is a staunch critique of what has become common and dominant Western modernity, and a staunch critique of Arab-Islamic thought that does not think differently and creatively from this "Western" modernity. The trusteeship paradigm tries to overcome the status quo by reinvigorating what it means to be free, human, rational, ethicist in attitude and ethical in practice. If there is a role for religion to play in the future, it is to fix some modern arrogance through applied ethics. ${ }^{4}$

However, while this is a well grounded argument, it does not solve the predicaments of modernity, either in the Islamic majority contexts or in modern contexts with which the trusteeship paradigm struggles intellectually. The interpretation of Islamic ethics differs. That is, freedom of thought and the rational faculties human beings enjoy do allow for a variety of appropriations of what it means to be ethical and ethicist, and what it means to be Islamically so (see, for instance, Shahab Ahmed, What is Islam?, 2015). To put it differently, if Abderrahmane critiques most classical Islamic philosophical scholarship for being mimetic of Greek thought, and critiques most modern Islamic intellectual scholarship for being mimetic of Euro-American (i.e. Western) thought, why would he propose his interpretation of Islamic thought not only as the most faithful to the core of religion, but also as the most capable of resolving

4 There is no need to mention that religion has its own forms of arrogance, and modernity has played a major role in addressing some of them, like the abolition of slavery, and equality of all before the law, despite one's religious or moral beliefs, ethnicity and appearances. 
its modern crises? And why would he make the whole classical "Islamic civilization" and current question of "Arab renewal" in particular bound to religious ethos, at a time when religiosity in modernity has transformed and has taken new forms that are different, if not unfaithful, to the classical tradition, even in the same domain he wishes to reform (i.e. the Arab world)?

Put otherwise, one would say that Abderrahmane is not pluralist, since a religious ethos does not give space to other "secular" forms of being and doing. While this argument could be understood, it is not tenable if the whole project of Abderrahmane is taken into account. His trusteeship paradigm, as I understand it, especially if read in the secular-liberal contexts of Europe for example, is anchored in religious ethos, and in Islam, but there is space for the other in it. Ethics, however Islamic they appear, are humanist, and universalist, as the different concepts and levels of spiritual elevation he speaks of show. The different other is part and parcel of this ethical paradigm of trusteeship.

Abderrahmane moves from the particular to the universal, and in this way he actually dismisses his own critique of "mimicry" since he cannot be universalist without founding his approach on the thought of his classical as well as modern predecessors. Systematic thought starts somewhere, and his starts locally before it moves to theorize for the future of humanity universally. This engagement with modernity and theorization for a future "civilization of ethos" as he calls it is what colours his project with universality. He goes beyond the local to the universal, unlike a lot of his contemporaries who do the opposite. They start universally then go local, and in doing so they lose contact with the local they wish to reform. Their universal discourse remains lost in abstraction, deprived of praxis. It is easy to talk of ethics but hard to apply them, that is what the trusteeship paradigm simply reminds us of. This proposed paradigm is a fertile scholarly endeavour, linguistically and argumentatively rich, spiritually profound. It will reverberate for generations to come, especially as change takes place in Arab societies, because of gradual secularization, industrialization, and technologization. Further critical study will unveil its scope and limitations.

\section{Acknowledgements}

Working on this paper took place over a long period of time, during which I gratefully benefited from some grants from the following institutions: the Department of Political Science of Luiss University of Rome, during the fourth year of my research fellowship (February 2017-February 2018), and a grant of a research fellowship conducted in Fscire-La Pira Center for Islamic History 
and Doctrines in Palermo between February 2019 and February 2020. The latter was awarded by the Italian Ministry of Foreign Affairs and International Cooperation, according to Art. 23-bis of DPR 18/1967. The positions in this paper exclusively represent those of the author. During these years I have also benefited from enriching discussions with various colleagues and scholars on the philosophy of Taha Abderrahmane, especially with Khalid Hajji and Mostapha Elmourabit, besides some exchanges with the philosopher himself, twice face-to-face and later on via email. I thank them warmly for their company. I also thank my colleagues in La Pira Center in Palermo for their comments on an earlier draft of this paper.

\section{References}

'Abd al-Laṭîf, Kamāl. 2o18. "Rūḥāniyyat Ṭāha 'Abd al-Raḥmān wa-As'ilat al-Tārīkh" [The Spirituality of Taha Abderrahmane and the Questions of History]. Al-faisal. o1 July. Accessed 15 February 2019. www.alfaisalmag.com/?p=11380.

Abderrahmane, Taha. 1979. Langage et philosophie: essai sur les structures linguistiques de l'ontologie [Language and Philosophy: Essays on the Ontology of Language Structure]. Rabat: Imprimerie de Fèdala-Publications de la faculté des lettres et des sciences humaines, Thèses et Mémoires $\mathrm{N}^{\circ} 3$.

Abderrahmane, Taha. 1985. Essai sur les logiques des raisonnements argumentatifs et naturels. Université de Paris-Sorbone, Paris IV. Thèse de Doctorat d'état ès-lettres et sciences humaines.

'Abd al-Raḥmān, Ṭāha. 1985. Al-Manțiq wa-l-Naḥw al-Ṣūrì [Formal Logic and Grammar]. Beirut: Dār al-Ṭal̄̄a lil-Ṭibā'a wa-l-Nashr.

'Abd al-Raḥmān, Ṭāha. 1987. F̄̃ Ușūl al-Hịwār wa-Tajdìd Ilm al-Kalām [On the Fundamentals of Dialogue and Renovation of Islamic Theology]. Casablanca and Beirut: al-Markaz al-Thaqāfī al-'Arabī.

'Abd al-Raḥmān, Țāha. 1989. Al-'Amal al-Dīnīwa-Tajdìd al-'Aql [Religious Practice and the Renewal of Reason]. Casablanca and Beirut: al-Markaz al-Thaqāfĩ al-'Arabī.

'Abd al-Raḥmān, Țāha. 1994. Tajdìd al-Manhaj fì Taqwìm al-Turāth [Renewing the Method of Assessing the Tradition]. Casablanca and Beirut: al-Markaz al-Thaqāfi al-'Arabī.

'Abd al-Raḥmān, Țāha. 1996. Fiqh al-Falsafa, ı: al-Falsafa wa-l-Tarjama [The Essence of Philosophy, Vol. 1: Philosophy and Translation]. Casablanca and Beirut: al-Markaz al-Thaqāfì al-'Arabī.

'Abd al-Raḥmān, Țāha. 1998. Al-Lisān wa-l-Mìzān aw al-Takawthur al-'Aqlī [Language and Balance, or the Multiplication of Reason] Casablanca and Beirut: al-Markaz alThaqāfī al-'Arabī. 
'Abd al-Raḥmān, Țāha. 1999. Fiqh al-Falsafa 2: al-Qawl al-Falsafi: Kitāb al-Mafhūm wa-lTa'thïl [The Essence of Philosophy, Vol. 2: On Philosophical Discourse: The Book of Concept and Etymology]. Casablanca and Beirut: al-Markaz al-Thaqāfì al-'Arabī.

'Abd al-Raḥmān, Ṭāha. 200o. Su’āl al-Akhlāq: Musāhama fì al-Naqd al-Akhlāqū lilHadātha al-Gharbiyya [The Question of Ethics: A Contribution to Ethical Criticism of Western Modernity]. Casablanca and Beirut: al-Markaz al-Thaqāfī al-'Arabī.

'Abd al-Raḥmān, Ṭāha. 20o1. “Ta‘addudiyyat al-Qiyam: Mā Madāhā wa-mā Ḥudūduhā?” [The Pluralism of Values: Scope and Limits]. Inaugural Speech, n. 3, October. Marrakech: Qāọī 'Iyāọ University, Faculty of Letters.

'Abd al-Raḥmān, Ṭāha. 2002. Al-Haqq al-'Arabìfì al-Ikhtilāf al-Falsafı̀ [The Arab Right to Philosophical Difference]. Casablanca and Beirut: al-Markaz al-Thaqāfì al-'Arabī. 'Abd al-Raḥmān, Ṭāha. 2003. Hiwārāt min Ajl al-Mustaqbal [Dialogues for the Future]. Casablanca and Beirut: al-Markaz al-Thaqāfì al-'Arabī.

'Abd al-Rahmmān, Ṭāha. 2005. Al-Haqq al-Islamī fì al-Ikhtilāf al-Fikrī [The Islamic Right to Intellectual Difference]. Casablanca and Beirut: al-Markaz al-Thaqāfī al-'Arabī.

'Abd al-Raḥmān, Țāha. 2006. Rūḥ al-Hadātha: Naḥwa al-Ta’sīs li-Hadātha Islāmiyya [The Spirit of Modernity: Introduction to Founding Islamic Modernity]. Casablanca and Beirut: al-Markaz al-Thaqāfī al-'Arabī.

'Abd al-Raḥmān, Țāha. 2007. Al-Hadātha wa-l-Muqāwama [Modernity and Resistance]. Beirut: al-, Ma'had al-Mac̄rif al-Ḥikamiyya lil-Dirāsāt al-Dīniyya wa-l-Falsafiyya.

'Abd al-Raḥmān, Tāha. 2012. Rūh al-Dīn [The Spirit of Religion: From the Narrowness of Secularism to the Openness of Trusteeship]. Beirut and Casablanca: al-Markaz al-Thaqāfì al-'Arabī.

'Abd al-Raḥmān, Ṭāha. 2012. Su'āl al-'Amal: Baḥth 'an al-Ușūl al-'Amaliyya lil-Fikr wa-lIlm [The Question of Doing: A Search for Practical Origins in Thought and Science]. Casablanca and Beirut: al-Markaz al-Thaqāfì al-'Arabī.

'Abd al-Raḥmān, Ṭāha. 2013. Al-Hiwwār Ufuqan lil-Fikr [Dialogue as a Horizon for Thought]. Beirut: al-Shabaka al-'Arabiyya lil-Abhāth wa-l-Nashr.

'Abd al-Raḥmān, Țāha. 2014. Bu's al-Dahrāniyya: al-Naqd al-I'timānī li-Faṣl al-Akhlāq 'an al-Din [The Misery of Secularism: Trusteeship Critique of the Separation of Ethics from Religion]. Beirut: al-Shabaka al-'Arabiyya lil-Abhāth wa-l-Nashr.

'Abd al-Raḥmān, Ṭāha. 2015. Su'āl al-Manhaj: Fì Ufuq al-Ta’sīs li-Unmūdhaj Fikrī Jadìd [The Question of Method: Toward a New Intellectual Paradigm]. Intr. Riḍwān Marhūm. Beirut: al-Mu’assasa al-'Arabiyya lil-Fikr wa-l-Ibdāc.

'Abd al-Raḥmān, Țāha. 2016. Min al-Insān al-Abtar ilā al-Insān al-Kawthar [From Sterile to Generous Humanity]. Beirut: al-Mu’assasa al-'Arabiyya lil-Fikr wa-l-Ibdāc.

'Abd al-Raḥmān, Țāha. 2016. Shurūd mā Ba'da al-Dahrāniyya: al-Naqd al-I'timānī lilKhurūj min al-Dīn [Post-Secular Loss: Trusteeship Critique of Deserting Religion]. Beirut: al-Mu’assasa al-'Arabiyya lil-Fikr wa-l-Ibdāc.

'Abd al-Raḥmān, Țāha. 2017. Dìn al-Hayā̉': Min al-Naqd al-I'timārì ilā al-Naqd al-I'timānī, 
Vol. 1/3: Ușūl al-Nazar al-I'timān̄̄ [The Religion of Testimony and Sight: From Imperative Thought to Trusteeship, Vol. 1/3: Foundations of Trusteeship Thinking]. Beirut: al-Mu'assasa al-'Arabiyya lil-Fikr wa-l-Ibdāc.

'Abd al-Raḥmān, Țāha. 2017. Dìn al-Hayā’': Min al-Naqd al-I'timārì ilā al-Naqd al-I'timānī, Vol. 2/3: al-Tahaddiyāt al-Akhlāqiyya li-Thawrat al-I lām wa-l-Ittișāl [The Religion of Testimony and Sight: From Imperative Thought to Trusteeship, Vol. 2/3: Ethical Challenges to the Revolution of Media and Communication]. Beirut: al-Mu'assasa al-Arabiyya lil-Fikr wa-l-Ibdāc.

'Abd al-Raḥmān, Țāha. 2017. Dìn al-Hayā̃: min al-Naqd al-I'timārīilā al-Naqd al-I'timānī, Vol. 3/3: Rūh al-Hijāb [The Religion of Testimony and Sight: From Imperative Thought to Trusteeship, Vol. 3/3: The Spirit of the Veil]. Beirut: al-Mu'assasa al'Arabiyya lil-Fikr wa-l-Ibdāc.

'Abd al-Raḥmān, Țāha. 2017. Su'āl al-'Unf: Bayna al-I'timāniyya wa-l-Hiwwāriyya [The Question of Violence: Between Trusteeship and Dialogue]. Beirut: al-Mu'assasa al'Arabiyya lil-Fikr wa-al-Ibdāc'

'Abd al-Raḥmān, Țāha. 2018. Thughūr al-Murābața: Muqāraba I'timāniyya li-Ṣirāāt alUmma al-Hāliyya [Posts of Resistance: A Trusteeship Approach to the Current Struggles of the Umma], Rabat: Maghareb Center for Civilizational Studies.

Ahmed, Shahab. 2015. What Is Islam? The Importance of Being Islamic. New York: Columbia University Press.

Amaqdūf, Mușțafā. 2018. Al-Insāniyyya Ufuqan lil-Tafkīr:Naḥwa Binā̉ Insāniyya JadīdaBahth fìFalsafat Ṭāha Abd al-Raḥmān [Humanity as a Horizon for Thought: Towards New Humanism-A Study in the Philosophy of Taha Abderrahmane]. Beirut: Markaz Mac̄āif and Casablanca: Dār al-Maqāsid.

Arhịla, 'Abbās. 2013. Faylasūf fì al-Muwājaha: Qirāa fì Fikr Ṭāha 'Abd al-Rạ̣mān [A Philosopher at the Forefront: A Reading in the Thought of Taha Abderrahmane]. Casablanca and Beirut: al-Markaz al-Thaqāfì al-'Arabī.

Al-'Arwī, 'Abdallāh. 2005. Khawāṭir al-Șabāh: Hajara fì al- Unuq, yawmiyyāt 1982-1999. Vol. 3. Beirut and Casablanca. Al-Markaz al-Thaqāfī al-'Arabī.

Bal'aqrūz, 'Abd al-Razzāq. 2017. Jawānib min Ijtihādāt Ṭāha 'Abd al-Raḥmān: alHadātha wa-l-Awlamawa-l-Aqlāniyya wa-l-Tajdìd al-Thaqäfi [Innovative Aspects in the Work of Taha Abderrahmane: Modernity, Globalization, Rationalism and Cultural Renewal]. Beirut: al-Mu'assasa al-'Arabiyya lil-Ibdāc wa-l-Nashr.

Balqazìz, 'Abd al-Ilāh. 2014. Naqd al-Turāth [Critique of the Tradition]. Beirut: Markaz Dirāsāt al-Waḥda al-'Arabiyya.

Belhaj, Abdessamad. 2018. "The Fall of The Western Family-Ṭāha 'Abd al-Rahmān's Critical Islamic Ethics." ReOrient 4 (1 Autumn): 24-43.

Bevers, Michael L. 2016. “Taha Abderrahman's Ethical Dialogue with the West.” Global Media Journal-Canadian Edition 9 (2): 121-126.

Bevers, Michael L. 2018. Islam, Globalization and Modernity: Approaching Global 
Ethics Through the Works of Taha Abderrahmane. PhD dissertation, Indiana University.

Bin 'Addī, Yūsuf. 2011. Mashrū' al-Ibdā' al-Falsafi al-Arabī: Qirāat fì A'māl Ṭāha 'Abd al-Rahmān [The Project of Arabic Philosophical Creativity: Reading Taha Abderrahmane]. Beirut: al-Shabaka al-Arabiyya lil-Abhāth wa-l-Nashr.

Borik, Monir. 2016. "Taha Abderrahman's Moral and Spiritual Foundations of Dialogue.” Global Media Journal - Canadian Edition 9 (2): 115-120.

Bū Zabra, 'Abd al-Salām. 2011. Țāha 'Abd al-Raḥmān wa-Naqd al-Hadātha [Taha Abderrahmane and the Critique of Modernity]. Riyad: Jadāwil.

Eyadat, Zaid, Francesca M. Corrao and Mohammed Hashas, eds. 2018. Islam, State, and Modernity: Mohammed Abed al-Jabri and the Future of the Arab World. New York: Palgrave MacMillan.

Habbāsh, Yūnus. 2018. Al-Khițāb wa-l-Hujaj 'ind Ṭāha 'Abd al-Rahmmān [Discourse and Argumentation in the Work of Taha Abderrahmane]. Beirut: Markaz Ma'ārif and Casablanca: Dār al-Maqāșid.

Hallaq, Wael B. 2013. The Impossible State: Islam, Politics, and Modernity's Moral Predicament. New York: Columbia University Press.

Hallaq, Wael B. 2019. Reforming Modernity: Ethics and the New Human in the Philosophy of Abdurrahman Taha. New York: Columbia University Press.

Ḥarb, 'Alī. 1996. "Ṭāha 'Abd al-Raḥmān wa-Mashrū'uh al-'Ilmī: Fiqh al-Falsafa li-Maḥw al-Falsafa" [Taha Abderrahmane and His Scholarly Project: Essence of Philosophy for the Demise of Philosophy]. Dirāsāt Arabiyya $3^{2}$ (May-June): 7-8. In Yūsuf Bin 'Addī. 2012. Mashrū'al-Ibdā'al-Falsafíal-'Arabī: Qirā'a fíA'māl Ṭāha 'Abd al-Rahmān [Innovative Arab Philosophy Project: A Reading in the Works of Taha Abderrahmane]. Beirut: al-Shabaka al-Áabiyya lil-Abhāth wa-l-Nashr: 18o-184.

Ḥarb, 'Alī. 1999. "Talīqan 'alā Tajribat Fiqh al-falsafa li-Ṭāha 'Abd al-Raḥmān: al-Tarjama al-Ta’șīliyya Bid‘a wa-Isti’ṣāl Ma'rifĩ lil-Ākhar” [Commenting on the Essence of Philosophy of Taha Abderrahmane: Authenticist Translation is a Myth and it is a Cognitive Erasure of the Other]. Al-Hayāt, o6 September. Accessed 28 January 2019. www.alhayat.com/article/1019148/- تعليقا-على-تجربة-فقه-الفلسفة-لطه-عبدالرمم-التربمة التأصيلية-بدعة-وهي-استئصال-معرفي-للآخر

Harī, 'Abd al-Nabī. 2014. Ṭāha 'Abd al-Raḥmān wa-Muḥammad 'Ābid al-Jābrī: Șirā' alMashrūayn 'alà Arḍ al-Hikma al-Rushdiyya [Taha Abderrahmane and Mohammed Abed al-Jabri: Dissent over the Averroist Wisdom]. Beirut: al-Shabaka al-'Arabiyya lil-Abhāth wa-l-Nashr.

Hashas, Mohammed. 2013. On the Idea of European Islam: Voices of Perpetual Modernity. PhD Dissertation. Luiss Guido Carli University, Rome.

Hashas, Mohammed. 2014. "Islamic Philosophy 3/3-The Question of Ethics: Taha Abderrahmane's Praxeology and Trusteeship Paradigm.” Resetdoc 17 (November). Accessed 15 March 2019. www.resetdoc.org/story/oooooo22452. 
Hashas, Mohammed. 2015. “Taha Abderrahmane's Trusteeship Paradigm: Spiritual Modernity and the Islamic Contribution to the Formation of a Renewed Universal Civilization of Ethos." Oriente Moderno 95: 67-105.

Hashas, Mohammed. 2019a. The Idea of European Islam: Religion, Ethics, Politics and Perpetual Modernity. London and New York: Routledge.

Hashas, Mohammed. 2019b. "The Arab Right to Philosophical Difference: The Concept of the Awakened Youth in the Political Philosophy of Taha Abderrahmane." In Islam in International Affairs: Politics and Paradigms. Eds. Nassef Manabilang Adiong, Raffaele Mauriello, and Deina Abdelkader. London and New Yok: Routledge: 39-61.

Humām, Muhammad. 2013. Jadal al-Falsafa al-Arabiyya bayna Muḥammad Ābid alJābrì wa-Ṭāha 'Abd al-Rahmmān-al-Baḥth al-Lughaw̄̄ Namūdhajan [Dialogue in Arab Philosophy: Mohamed Abed al-Jabri and Taha Abderrahmane-Linguistic Inquiry in Focus]. Beirut: al-Markaz al-Thaqāfī al-'Arabī and Rabat: Mominoun Without Borders.

Al-Jābrī, Muḥammad 'Ābid. 1993. Ḥafriyyāt fì al-Mușțalaḥ al-Turāthī: Muqārabāt Awwaliyya [The Archeology of the Classical Concept: Preliminary Approaches]. In Taha Abderrahmane, ed. Al-munāzara 6, 1 December: 9-24.

Jad‘ān, Fahmī. 2014. "Al-Usus al-Dīniyya wa-l-Falsafiyya lil-Qiyam al-Akhlāqiyya” [Religious and Philosophical Foundations of Ethical Values]. Majallat al-Bāb of Mominoun Without Borders 1: 13-23.

Kigar, Samuel. 2015. "Arguing the Archive: Țāha 'Abd al-Raḥmān, Muḥammad 'Ābid alJābirī, and the Future of Islamic Thought." Comparative Islamic Studies 11 (1): 5-33.

Lahoud, Nelly. 2005. Political Thought in Islam: A Study in Intellectual Boundaries. London and New York, Routledge.

Le Nouveau Magazine Littéraire. 2019. Les 35 penseurs qui influencent le monde pour le meilleur et pour le pire [The 35 Thinkers that Influence the World for Good or Bad]. N. 13, Janvier.

Mashrūh, Ibrāhīm, 20o9. Ṭāha Abd al-Raḥmān:Qirāa a fìMashrū ih al-Fikrī [Taha Abderrahmane: A Reading in His Philosophical Project]. Beirut: Markaz al-Ḥadāra liTanmiyat al-Fikr al-Islāmī.

Maqūra, Jallūl. 2015. Falsafat al-Tawāṣul fì al-Fikr al-'Arabī al-Mu'ạșir: Ṭāha 'Abd alRaḥmān wa-Nāṣîf Nașṣār bayna al-Qawmiyya wa-l-Kawniyya [The Philosophy of Communication in Contemporary Arab Thought: Taha Abderrahmane and Nasif Nassar between Nationalism and Globalism]. Beirut: Markaz Dirāsāt al-Waḥda al'Arabiyya.

Mimouni, Chokri. 2016. “Taha Abderrahman dans la lignée des philosophes de l'Occident Musulman." Global Media Journal -Édition canadienne 9 (2): 27-39.

Moosa, Ebrahim. 2014. "On Reading Shatibi in Rabat and Tunis." The Muslim World Journal 104: 451-464.

Al-Naqqārī, Hạmū. 2014. Manțiq Tadbīr al-Ikhtilāf min Khilāl A'māl Ṭāha 'Abd al- 
Rahmmān [Management of Difference in the Work of Taha Abderrahmane]. Beirut and Casablanca: al-Shabaka al-'Arabiyya lil-Abhāth wa-l-Nashr.

Al-Sayyid, Riḍwān. 2012. "Ṭāha 'Abd al-Raḥmān fī Rūḥ al-Dīn wa-Ḥimāyat al-Dīn min alIslām al-Siyāsī fī Azminat al-Taghyīr" [Taha Abderrahmane in the Spirit of Religion and the Protection of Religion from Political Islam in the Age of Transformation]. Al-Hayāt. 21 July. Accessed 15 February 2019. www.alhayat.com/article/341823/-طه عبد-الرحن-في-روح-الدين-وماية-الدين-منالسلام-السياسي-في-أزمنة-التغيير

Al-Sayyid, Riḍwā̄n. 2018. "Fișāmāt al-Wāqi' wa-l-Wacy ladā al-Muthaqqafinn al-'Arab" [The Gap between Reality and Consciousness among Arab Intellectuals]. Al-Sharq al-Awsaț, 30 November. Accessed 15 February 2019. www.aawsat.com/home/art-

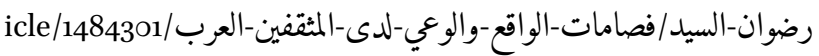

Sayyid Wald Abāh, 'Abdallāh. 2010. A'Tām al-Fikr al-'Arabī: Madkhal ilā Khārițat al-Fikr al-Arabī al-Rāhina [Figures of Arab Thought: An Introduction to the Map of Contemporaray Arab Thought]. Beirut: al-Shabaka al-'Arabiyya lil-Abhāth wa-l-Nashr.

Al-Shabba, Muḥammad. 2016. 'Awā’iq al-Ibdā' al-Falsafì al-'Arabì Hasb Ṭāha 'Abd alRahmān [Impediments to Innovative Arab Philosophy according to Taha Abderrahmane]. Beirut and Rabat: Kalima and Dār al-Amān.

Tais, Miloud Amine. 2018. Between Revivalism and Reconstructionism: Islam, Reform, and Secularism in the Works of Taha Abderrahmane and Mohammed Arkoun. $\mathrm{PhD}$ dissertation, Georgetown University, Graduate School of Arts \& Sciences. 